\title{
Evapotranspiration Studies for Protective Barriers: \\ FY 1989 Status Report
}

\author{
S. O. Link \\ M. E. Thiede \\ J. L. Downs \\ D. ). Lettau \\ W. J. Waugh(a)
}

May 1992

Prepared for the U.S. Department of Energy under Contract DE-AC06-76RLO 1830

Pacific Northwest Laboratory Richland, Washington 99352

(a) Geotech

Grand Junction, Colorado.

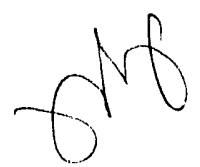




\section{EXECUTIVE SUMMARY}

This document describes the results of technological developments and experiments at the Small 'Tube Lysimeter Facility. The objective of this research is to develop the capability to predict evapotranspiration in support of studies of water infiltration control for the Hanford Protective Barrier Development Program. Evapotranspiration is the combined loss of water from plants and soil surfaces to the atmosphere. This process must bf predictable to aclequately model soil water dynamics.

We developer a miniature greenhouse (gas exchange chamber), where internai temnsiature and relative humidity can be controlled. With this device we measure, evapotranspiration, transpiration, and carbon dioxide exchange rates from lysimaters with various surface and plant characteristics. We tested the effest on gas exchange rates of sand, gravel, admix, and soil surfaces in lysimeters where, cheatgrass, Bromus tectorum, had been seeded. Results showed that evapotranspiration was unaffected by the surface treatments. Estimated transpiration rates were higher for plants growing in sand compared with rates for plants growing in the admix and soil treatments. Soil evaporation rates were higher in the gravel treatment than in the sand treatment. Future research will entail parameterization of relationships between evapotranspiration, transpiration, soil evapcration, carbon dioxide exchange, and the abiotic and biotic factors that drive these processes for model development. 


\section{ACKNOWLEDGMENTS}

This research was funded by the U.S. Department of Energy. The authors gratefully acknowledge discussions with Glendon Gee of Pacific Northwest Laboratory and the technical assistance of Mary Jo Harris. 


\section{CONTENTS}

EXECUTIVE SUMMARY ........................................................................................

ACKNOWLEDGMENTS .................................................................................

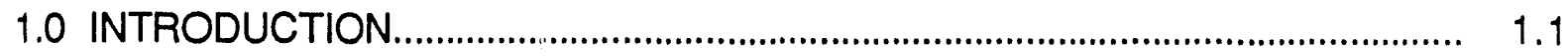

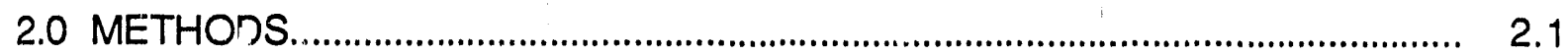

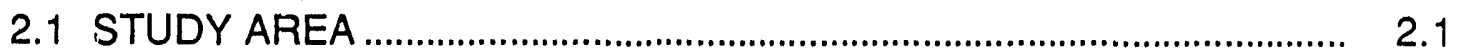

2.2 EXPERIMENTAL DESIGN............................................................. 2.1

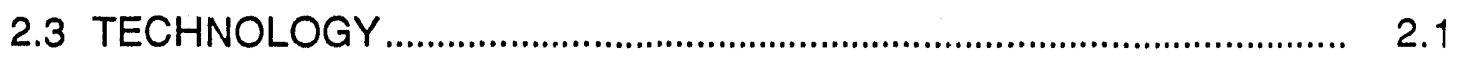

2.3.1 Whole Plant Gas Exchange System ...................................... 2.1

2.3.2 Leaf Area ................................................................................. 2.3

2.3.3 Xylem Pressure Potential ............................................................ 2.3

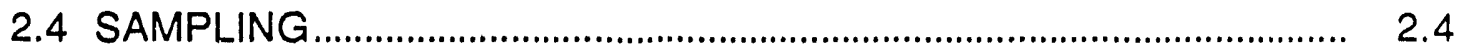

2.5 DATA ANALYSES …………........................................................... 2.4

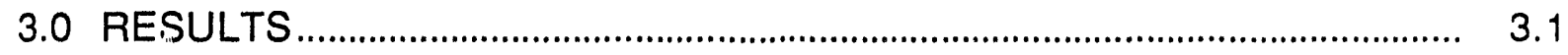

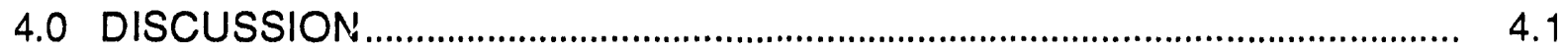

5.0 FUTURE WORK ..................................................................................... 5.1

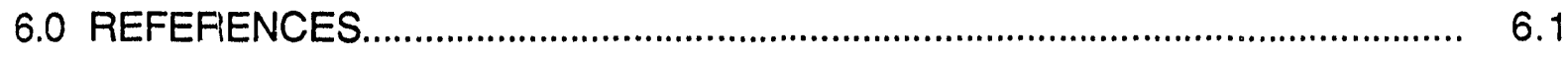




\section{EIGURES}

3.1 Effect of Air Pressure Within the Gas Exchange Chamber on Soil Evaporation

3.2 Effect of Surface Treatments on Cheatgrass Leaf Area Development

3.3 Effect of Surface Treatments on Evapotranspiration.

3.4 Effect of Surface Treatments on Net $\mathrm{CO}_{2}$ Uptake.

3.5 Effect of Surface Treatments on Soil Evaporation.

3.6 Effect of Surface Treatments on Soil Respiration.

3.7 Effect of Surface Treatments on Cheatgrass Transpiration

3.8 Effect of Surface Treatments on Cheatgrass Net Photosynthesis.

3.9 Effect of Surface Treatments on Mid-day Xylem Pressure Potential of Cheatgrass 


\subsection{INTRODUCTION}

Pacific Northwest Laboratory (PNL) and Westinghouse Hanford Company (WHC) are working together to develop protective barriers for the near-surface disposal of radioactive and hazardous waste at Hanford. The proposed barrier design consists of a layer of fine-textured soil overlying a series of layers grading from sand to basalt riprap (USDOE 1987). A multiyear research program is being conducted to assess the long-term performance of barrier configurations in restricting plants, animals, and water from contacting buried wastes (Adams and Wing 1986).

The purpose of this report is to review work done in FY 1989 on the evapotranspiration subtask of the Small Tube Lysimeter Facility (STLF) experiment. The STLF was designed to measure the influence of erosion control practices and alternative barrier layer configurations on water movement within and extraction from the barrier by evapotranspiration (Waugh and Link 1989). A summary of progress to date at the STLF can be found in Relyea et al. (1989).

As stated in the test plan (Link and Waugh 1989), specific objectives of PNL's evapotranspiration work were to:

1. develop and test an environmentally controlled whole plant gas exchange system

2. collect evapotranspiration data at the whole plant level on the small tube lysimeters

3. collect transpiration data on shrubs at McGee Ranch

4. collect data necessary to parameterize the plant component of the UNSAT-H code.

This report describes the results for objectives 1 . and 2. accomplished in FY 1989. Results for objective 3. were presented in Link et al. (1989). Work on objective 4. was done in FY 1990. The ultimate purpose of this work is to improve the parameterizaton of plant processes in hydrology models, which will be used to test the performance of barrier structures. 


\subsection{METHODS}

\subsection{STUDY AREA}

The Small Tube Lysimeter Facility (STLF) is located adjacent to the Field Lysimeter Test Facility (FLTF). Descriptions of the study area are given in Gee et al. (1989) and Waugh and Link (1989).

\subsection{EXPERIMENTALDESIGN}

A description of the experimental design for the STLF is given in Waugh and Link (1989). The gas exchange experiments were conducted on a subset of the treatments described in Waugh and Link (1989). Observations were taken in the sand $(20 \mathrm{~cm})$, gravel $(7 \mathrm{~cm})$, and admix $(20 \mathrm{~cm})$ over fine soil and all fine soil lysimeter treatments with cheatgrass growing in them and experienced ambient or twice longterm average precipitation with water applied as single monthly irrigations. In winter and spring 1989, ambient precipitation was nearly twice average precipitation. Observations were taken with cheatgrass present and after shoots were removed. With shoots present, water vapor exchange is considered evapotranspiration. With shoots removed, water vapor exchange is due to soil evaporation. Three to five replicates were observed for treatment. Data were collected between May 9 and June $2,1989$.

\subsection{IECHNOLOGY}

Technology used in this work is explained in Waugh and Link (1989) and Link et al. (1989). This report describes in more detail the configuration of the whole plant gas exchange system as used in this experiment.

\subsubsection{Whole Plant Gas Exchange System}

The whole plant gas exchange system is portable so that measurements can be made at remote sites where utilities are unavailable. Instrumentation is housed in a motor home, which is climate controlled. Power was supplied by an 87-amp diesel generator. Power for the instruments was filtered by a line conditioner. Cooling water was provided by a water chiller and circulated through the system in a closed loop with 
a water pump. Water lines to the chamber air conditioning unit were $30 \mathrm{~m}$ long and were insulated by $3-\mathrm{cm}$-thick closed cell foam wrappings.

The whole plant gas exchange system was patterned after that described in Caldwell et al. (1983) and is an open system. Carbon dioxide concentrations were measured with an ADC 225 MKIII (Analytical Development Co. Ltd., Hoddesdon, England) infrared gas analyzer (IRGA). An accompanying gas routing device (WA357, Analytical Development Co. Ltd., Hoddesdon, England) allowed for computercontrolled calibration and measurement in absolute and differential modes. Calibration of the IRGA sccurred before each lysimeter was observed. Measurement of water vapor concentrations entering and leaving the gas exchange chamber was accomplished with two DEW-10 dewpoint hygrometers (General Eastern Instruments, Inc., Watertown, MA). Dewpoint temperature was measured with RTD platinum resistance sensors. All other temperatures were measured with fine wire copper-constantin thermocouples. These included leaf temperature, chamber air temperature, heat exchanger fin temperature, and air temperature in air lines just ahead of the dewpoint hygrometers. Photosynthetically active radiation (PAR) was measured with a Li-Cor 190SB Quantum sensor (Li-Cor Inc., Lincoln, NE). Supplemental lighting was provided by a 300-W quartz filament slide projector bulb suspended over the gas exchange chamber when skies were overcast. This light provided full-sun-equivalent light conditions as measured at the top of the canopy.

The gas exchange chamber used for these experiments is constructed of clear acrylic plastic. The chamber is cylindrical $(65 \mathrm{~cm}$ tall and $30 \mathrm{~cm}$ in diameter) with a flat plastic top having a volume of $46 \mathrm{~L}$. The chamber is lined with clear Teflon tape to minimize gas absorption by the plastic (Bloom et al. 1980). The seal between the chamber and the lysimeter is made with an aluminum ring lined with closed-cell foam, which is constructed to conform to the aluminium lifting tabs of the lysimeter. The ring has grooves lined with closed-cell foam on the other side to seal the chamber. The chamber has an inlet for recirculating air $22 \mathrm{~cm}$ below a similar outlet port. These ports are $5 \mathrm{~cm}$ in diameter. An air conditioning unit is attached to the ports to control temperature. The air conditioning unit housing is fabricated with stainless steel and is air tight. Temperature is controlled with Peltier chips, heat exchange fins, and a circulating fan.

The heat exchange fins are made of nickel-plated copper. The heat exchanger and fan motor (located outside the air conditioning unit) are water cooled. The air conditioning housing is insulated with $0.64-\mathrm{cm}$-thick closed-cell foam, which is cov- 
ered with aluminum foil to reflect solar radiation. The housing is always placed on the north side of the lysimeter to avoid shading the plants.

Process air was taken from a height of $1.5 \mathrm{~m}$ by an oilless air compressor, passed through a chilled water jacket to remove water from the air, and maintained at a pressure of 40 psi ahead of two air filters and a Tylan (FC-262) mass flow controller. The mass flow controller was used to control the flow of air to maintain a constant chamber dewpoint temperature. All air liries were Bev-e-lin tubing. Sample lines were diverted to measure the dewpoint temperature and $\mathrm{CO}_{2}$ concentration (in absolute and differential mode) of the air going into the chamber. Sample air was pumped out of the chamber through Bev-e-iin tubing to determine dewpcint temperature and $\mathrm{CO}_{2}$ concentration of the air leaving the chamber.

Data were acquired and instruments controlled with a WB-820 board system (Omega Engineering, Inc.) in association with an IBM-AT microcomputer.

\subsubsection{Leaf Area}

Total green leaf and stem area was non-destructively estimated after each gas exchange observation. This was done by classifying shoot parts into size sets, measuring leaf and stem characteristics, and counting the number of elements in each set within a lysimeter. Leaf area was computed as follows:

$$
A=\sum_{j=1}^{m} \sum_{i=1}^{n} l_{i j}{ }^{*} w_{i j}+(\pi / 2) * \sum_{j=1}^{m} \sum_{i=1}^{n} h_{i j}{ }^{*} d_{i j} \text {, }
$$

where $A=$ total leaf and stem area

$I=$ leaf length

$w=$ leaf width

$\mathrm{h}=$ stem height

$d=$ stem diameter

$i=$ number of elements within each of the $j$ size classes. 


\subsubsection{Xylem.Pressure Potential}

Xylem pressure potential of leaves was measured with a pressure bomb (Soil Moisture Equipment Corp., Santa Barbara, CA) taking the precautions of maintaining a humid atmosphere in the chamber with a damp towel, taking measurements immediately after cutting leaf material, and pressurizing the chamber slowly and consistently for all obsenvations.

\subsection{SAMPLING}

Up to five lysimeters were measured between 09:00 and 15:00 h, depending on conditions on any given day. Lysimeters with plants in them were observed first over a number of days; then the plants were clipped, and observations were taken again to measure soil evaporation and respiration. Plant transpiration and net photosynthetic rates were estimated by subtracting gas exchange data collected from lysimeters after plants had been clipped from the data collected before the plants were clipped. Chamber conditions were as follows: chamber air temperature $\left(25.0 \pm 0.5^{\circ} \mathrm{C}\right)$, chamber dewpoint temperature $\left(8.5 \pm 1^{\circ} \mathrm{C}\right)$, full light, chamber $\mathrm{CO}_{2}$ concentration of $345 \pm 5 \mathrm{ppm}$, and an overpressure of $2.5 \pm 2.0 \mathrm{~cm} \mathrm{H}_{2} \mathrm{O}$.

\subsection{DATA ANALYSES}

Data are presented as means with 1 standard error bar. Treatment comparisons are made with Duncan's Multiple Range Test at the $95 \%$ confidence level (Duncan 1975). 


\subsection{BESULTS}

The focus of this work was to determine the effect of surface covers on transpiration and evapotranspiration from the lysimeters. Three experimental approaches were used to investigate these effects. One way to separate the processes controlling evapotranspiration (plant transpiration and soil evaporation) on undisturbed surfaces is to maintain a positive pressure in the chamber. Positive pressure is believed to reduce the flux of water from the soil while not affecting plant transpiration. Thus, the first test examined the effect of positive pressure on soil evaporation (Figure 3.1). Over the range of chamber pressures imposed on the system, no clear reduction of soil evaporation was observed with increasing pressure.

Observed leaf area of cheatgrass was strongly affected by surface treatments (Figure 3.2). Leaf area in the sand treatment was less than half that in the admix and soil treatments. Neither evapotranspiration nor net $\mathrm{CO}_{2}$ flux, the combined $\mathrm{CO}_{2}$ flux of plant and soil, based on the surface area of the lysimeters, was influenced by the surface treatments (Figures 3.3 and 3.4).

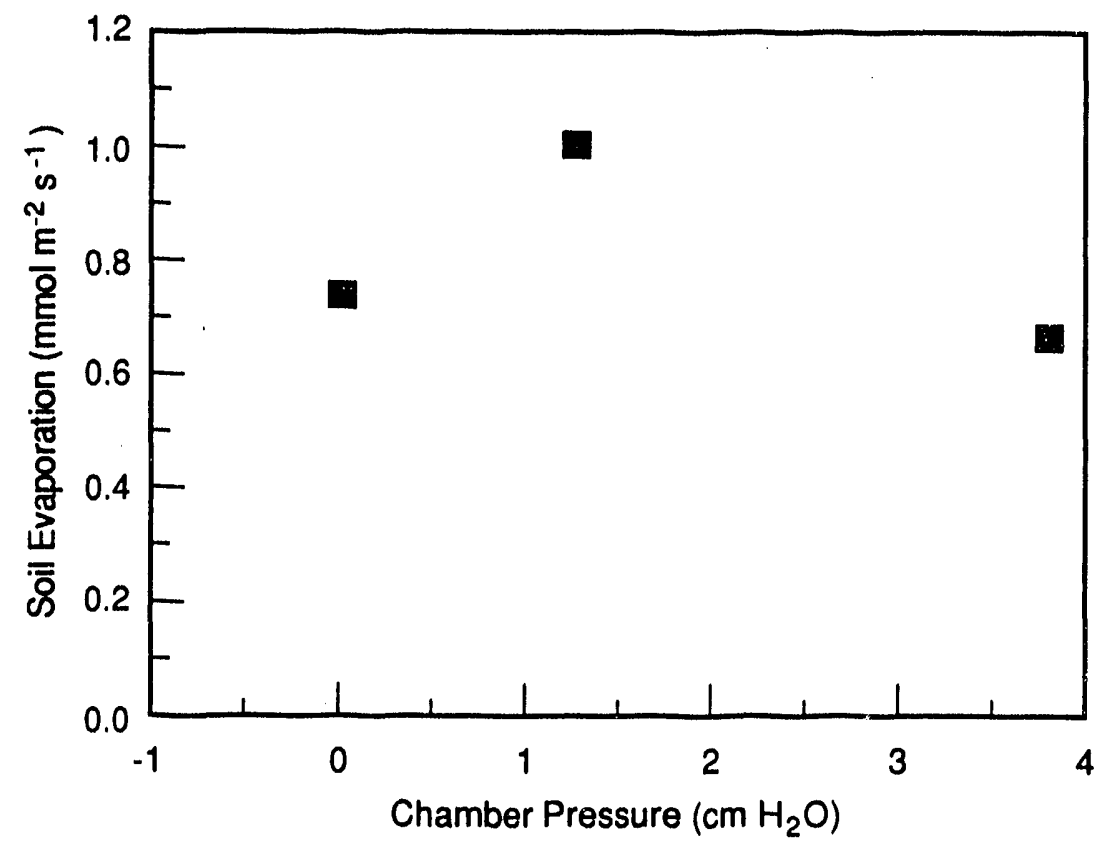

S9111019.1

FIGURE 3.1. Effect of Air Pressure Within the Gas Exchange Chamber on Soil Evaporation 


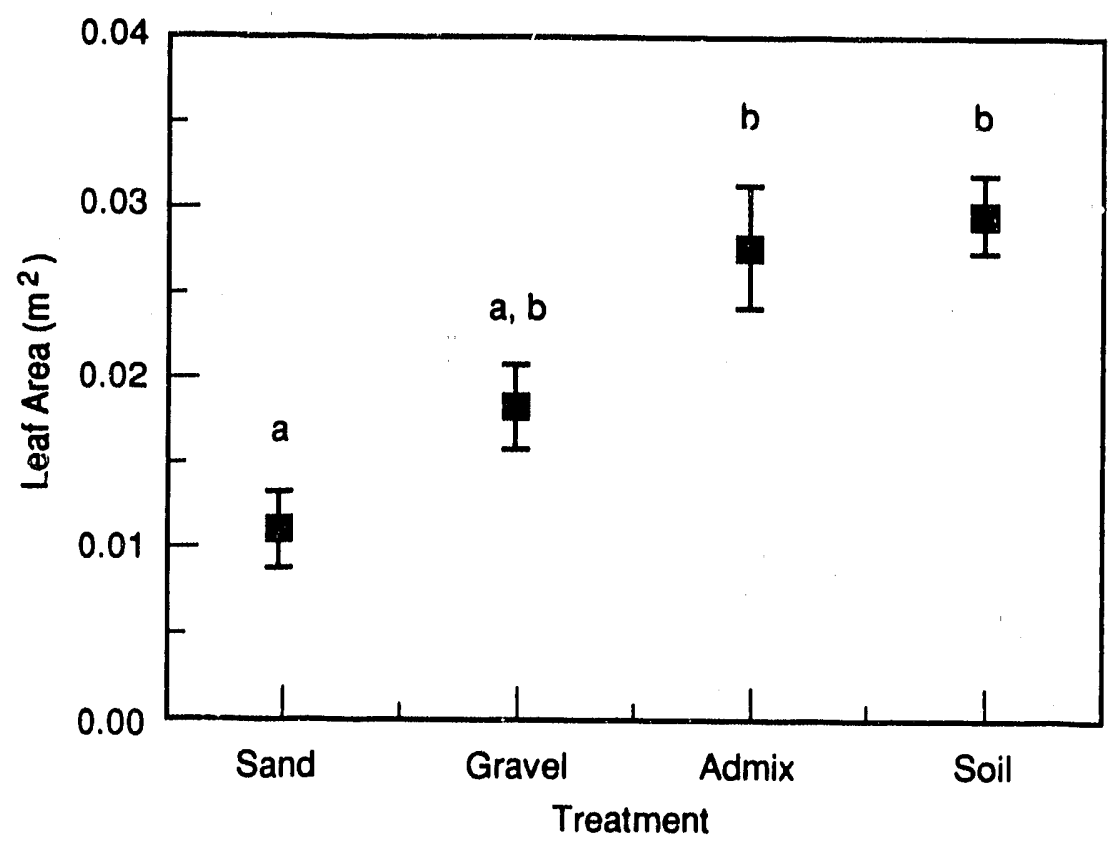

S9111019.2

FIGURE 3.2. Efferit of Surface Treatments on Cheatgrass Leaf Area Development. Means with the same letter are not significantly different $(p=0.05, n=5)$ by Duncan's Multiple Fiange Test

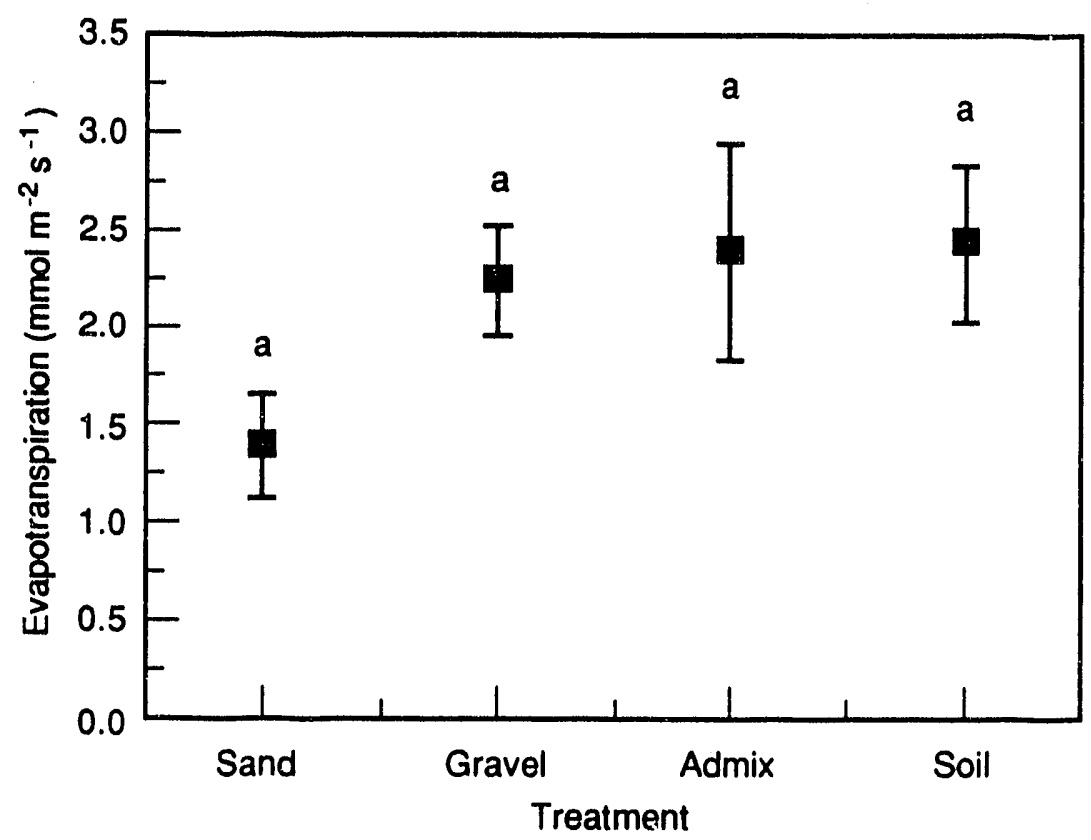

59111019.3

FIGURE 3.3. Effect of Surface Treatments on Evapotranspiration. Rates are based on the area of each lysimeter. Means with the same letter are not significantly different ( $p=0.05, n=3$ to 5 ) by Duncan's Multiple Range Test. 


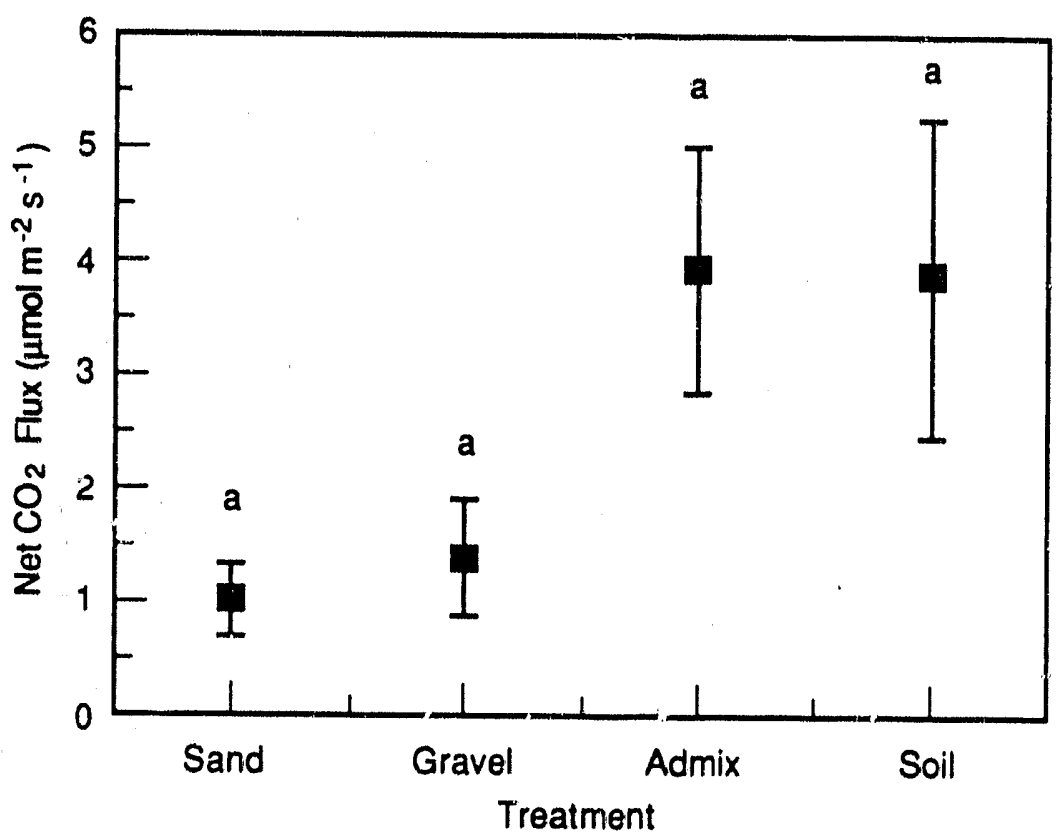

S9111019.4

ElGURE 3.4. Effect of Surface Treatments on Net $\mathrm{CO}_{2}$ Uptake. Rates are based on the area of each lysimeter. Means with the same letter are not significantly different ( $p=0.05, n=3$ to 5 ) by Duncari's Multiple Range Test.

Soil evaporation rates appear to be infiluenced by surface treatments based on data obtained after shoot material had been removed from the lysimeters (Figure 3.5). Evaporation rates were nearly three times greater in the gravel treatment than in the sand treatment. Evaporation rates in the admix and soil treatments were not significantly different from evaporation rates in the sand or gravel treatments.

Evaporation rates were only $20 \%$ of evapotranspiration rates for the sand, admix, and soil treatments and $30 \%$ of that in the gravel treatment.

Soil respiration rates were also dependent on the surface treatments with rates in the soil treatment twice as great as in the sand treatment (Figure 3.6). Soil respiration rates in the gravel and admix treatments were not significantly different than rates in the soil or sand treatments.

Treatment effects were apparent for estimated transpiration rates (Figure 3.7). Transpiration rates were greater in the sand treatment than in the admix and soil treatments. Transpiration rates were the same in the sand and gravel treatments. 
There were no significant effects of surface treatment on estimated net photcsynthetic rates (Fig. 3.8). Xylem pressure potential was signficantly affected by the surface treatments (Fig. 3.9). Xylem pressure potential was significantly greater in the gravel treatment than in the admix treatmeni while values in the sand and soil treatments were rot significantly different than in either the gravel or admix treatments.

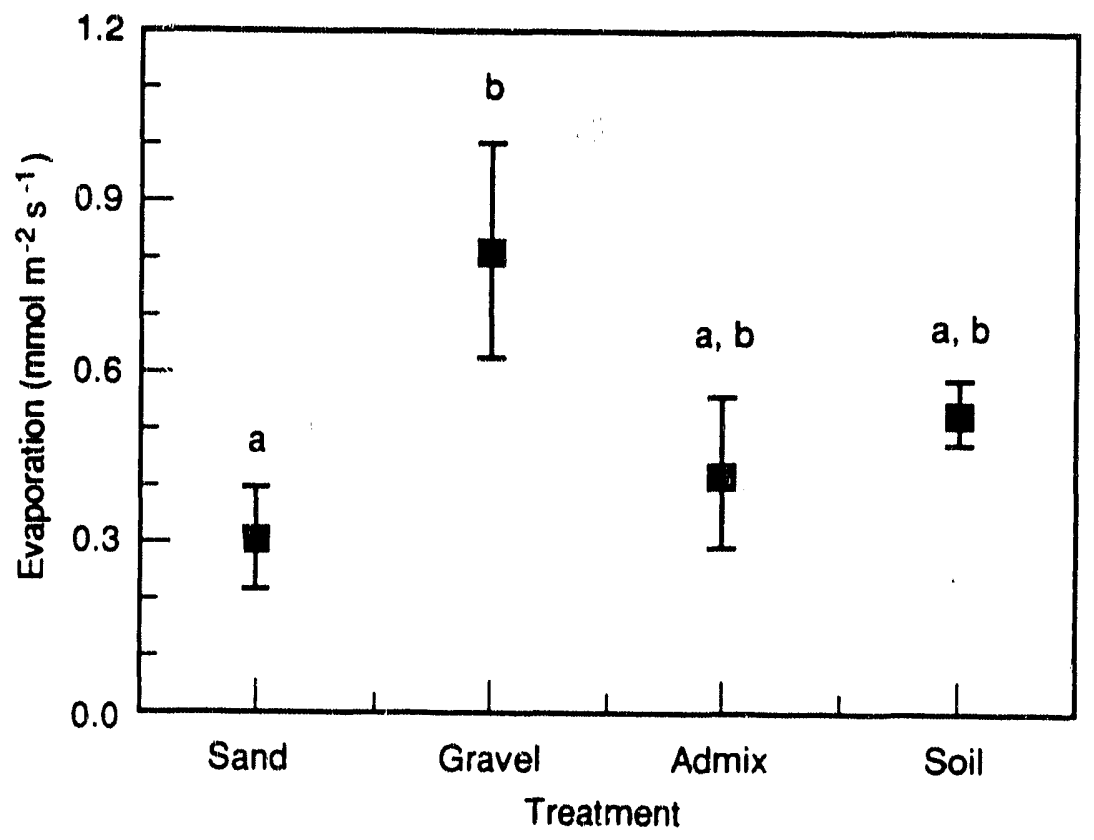

S9111019.5

FIGURE 3.5. Effect of Surface Treatments on Soil Evaporation. Rates are based on the area of each lysimeter. Means with the same letter are not significantly different $(p=0.05, n=3)$ by Duncan's Multiple Range Test. 


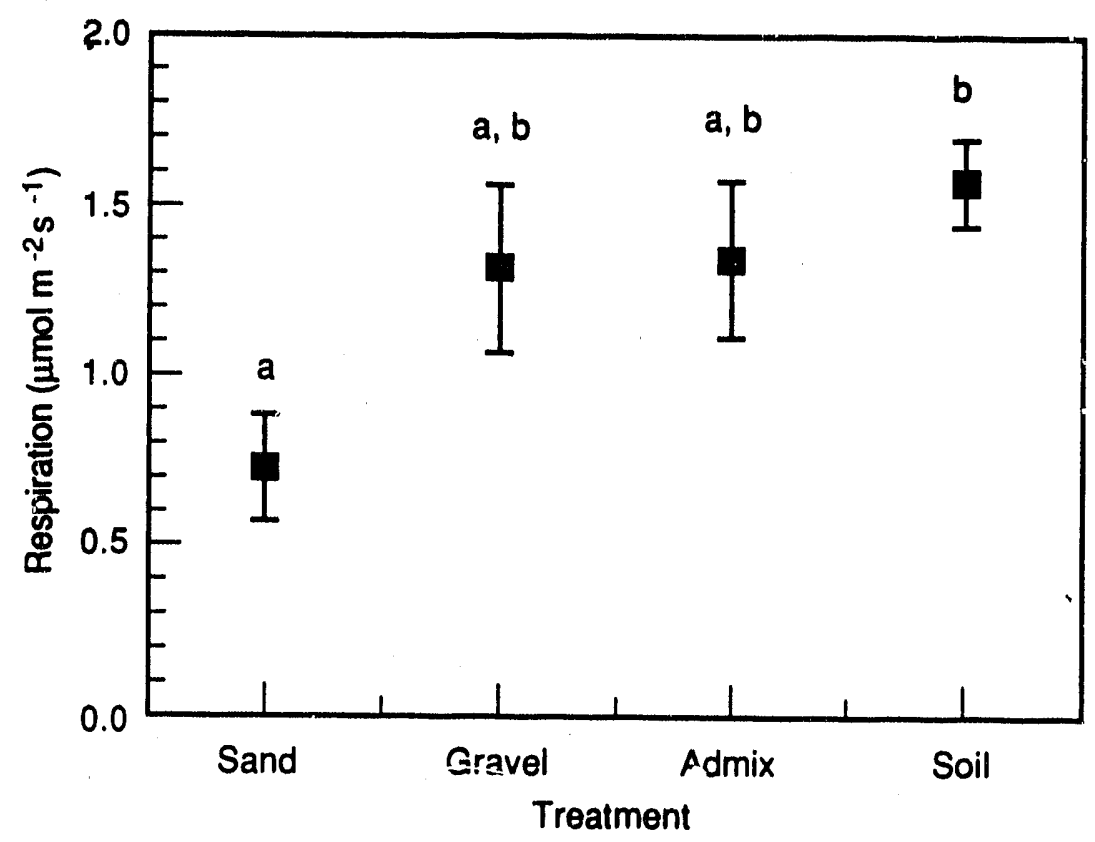

$\mathbf{S} 9111019.6$

EIGURE 3.6. Effect of Surface Treatments on Soil Respiration. Rates are based on the area of each lysimeter. Means with the same letter are not significar-tly different $(p=0.05, n=3)$ by Duncan's Multiple Range Test.

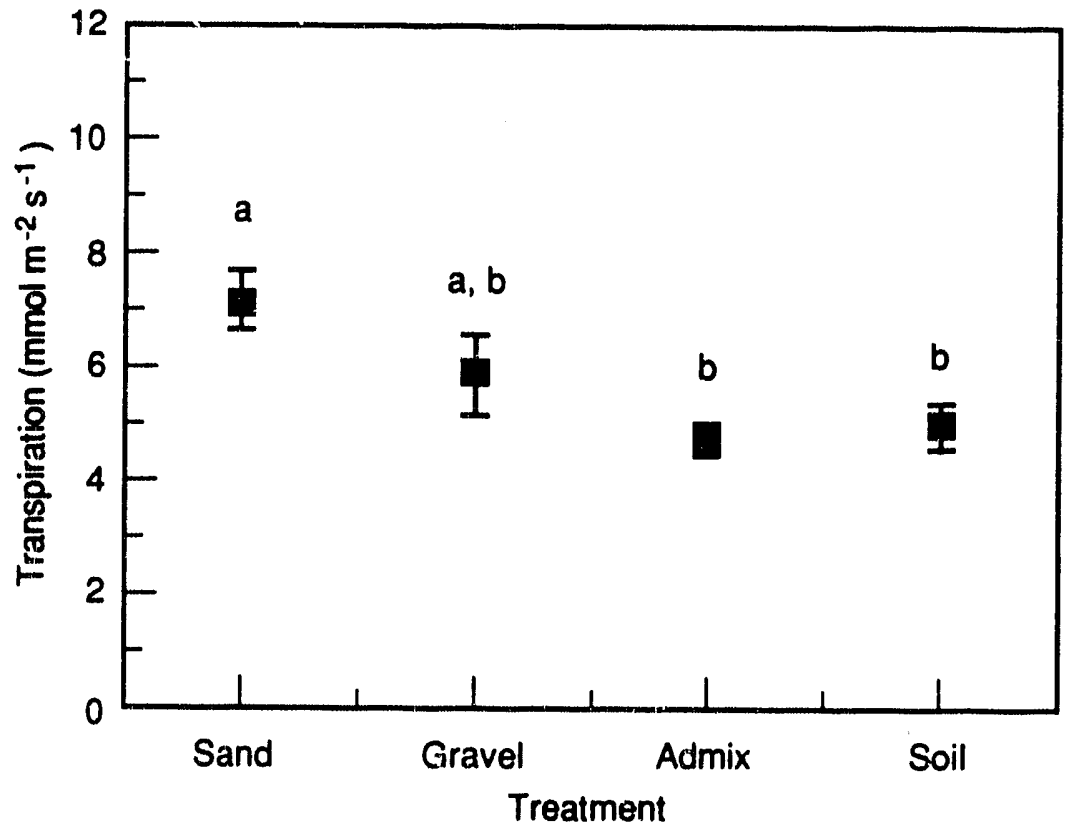

S 9111019.7

FIGURE 3.7. Effect of Surface Treatments on Cheatgrass Transpiration. Rates are based on single-sided leaf area of plants in each lysimeter. Means with the same letter are not significantly different $(p=0.05, n=3)$ by Duncan's Multiple Range Test. 


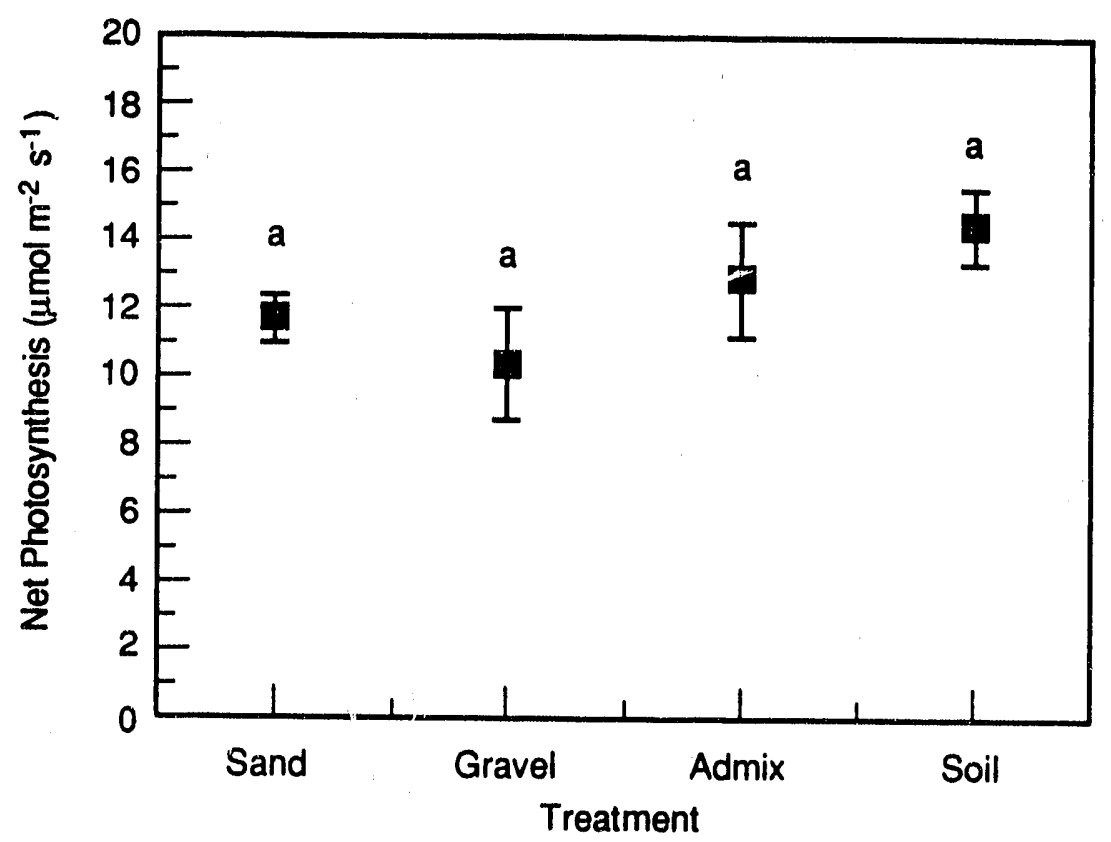

S9111019.8

ElGURE 3.8. Effect of Surface Treatments on Cheatgrass Net Photosynthesis. Rates are based on single sided leaf area of plants in each lysimeter. Means with the same letter are not significantly different $(p=0.05, n=3)$ by Duncan's Multiple Range Test.

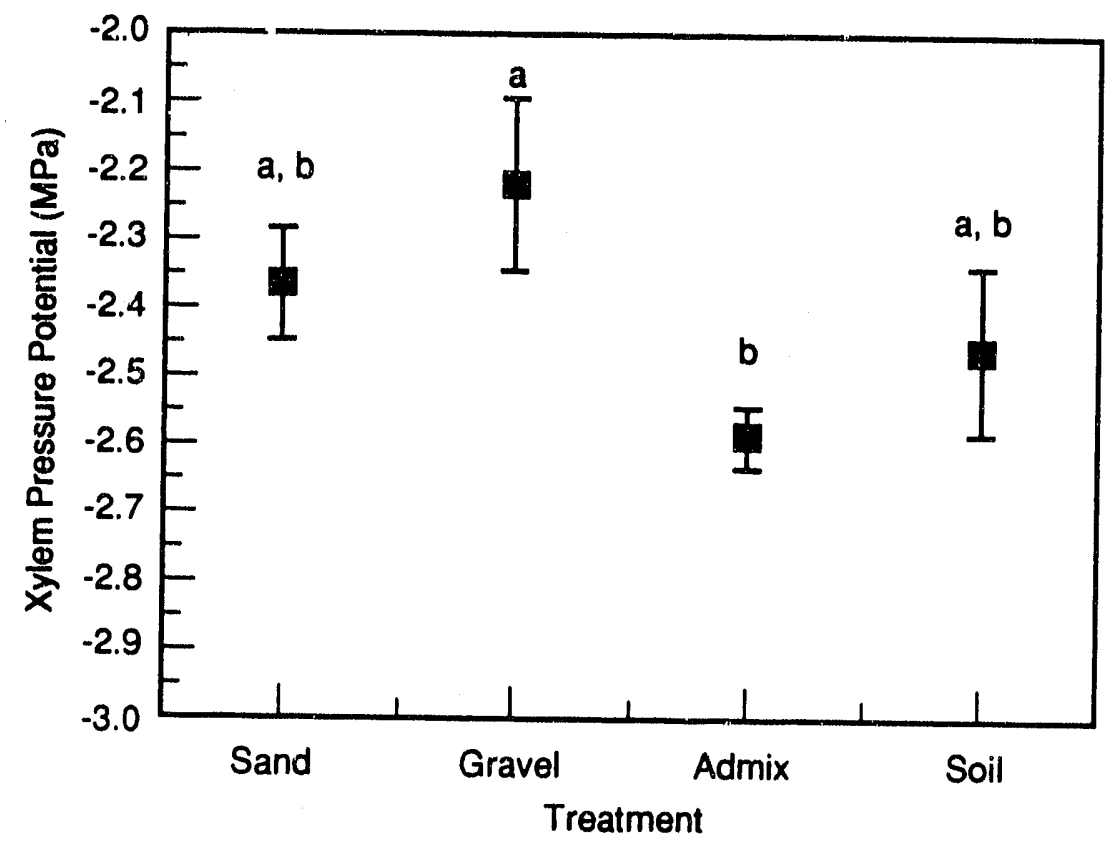

S9111019.9

FIGURE 3.9. Effect of Surface Treatments on Mid-day Xylem Pressure Potential of Cheatgrass. Means with the same letter are not significantly different $(p=0.05, n=5)$ by Duncan's Multiple Range Test. 


\subsection{DISCUSSION}

The purpose of the work done in FY 1989 was to 1) develop and test an environmentally controlled whole plant gas exchange system, and 2) collect evapotranspiration data at the whole-plant level on the small tube lysimeters. This was successfully accomplished.

The development of the gas exchange systom was, for the most part, accomplished in the laboratory before the field season began. In the field, other technical problems had to be solved because of the lack of electrical power and running water at the study site. These two problems were solved by int r rating a diesel-powered electrical generator and a closed-loop wate cooler and circulation system into the system. The entire sas exchange system is now truly portable.

The two critical control variables, chamber temperature and chamber dewpoint temperature, were satisfactorily controlled in the field. Chamber temperature was controlled to within $0.5^{\circ} \mathrm{C}$ of the setpoint temperature, and chamber dewpoint temperature was controlled to within $1.0^{\circ} \mathrm{C}$ of the setpoint dewpoint temperature. Actually, the chamber dewpoint temperature control was tighter than $1.0^{\circ} \mathrm{C}$ for most observations when there was a relatively high evapotranspiration rate. Relatively poor dewpoint temperature control occurred only when the rate of evapotranspiration was so low that the flow controller regulating the flow of dried outside air into the chamber was forced to operate at the low end of its operating range. This occurred with some observations on apparently dry soil without plant material. This problem can be solved by humidifying the incoming air supply or incorporating a flow controller with a lower operating range. Overall, the current level of contro! is adequate for most purposes such as parameterizing driving relationships for gas exchange processes for model development.

The other technical question investigated was the effect of maintaining a positive pressure within the chamber to suppress soil gas exchange. This has been done, as discussed by Tranquillini and Caldwell (1972), to separate plant gas exchange from soil gas exchange processes. Within the range of pressures investigated, we found no clear effect of positive pressure on soil evaporation or soil respiration.

Tranquillini and Caldwell (1972) suggested that positive pressures be maintained between $5 \mathrm{~cm}$ and $13 \mathrm{~cm} \mathrm{H} \mathrm{H}_{2} \mathrm{O}$ to suppress soil gas exchange processes. Unfortunately, in our experiments, we were only able to maintain pressures up to $4 \mathrm{~cm}$ 
$\mathrm{H}_{2} \mathrm{O}$ because of leak problems and low flow rates over the molatively dry soils. Future tests can be done to investigate the effect of higher operating pressures on soil gas exchange processes by working at lower dewpoint temperatures, which will necessitate higher flow rates, and consequently. isier pressure control.

The other objective of this work $w$. collect data on the effect of surface treatments on evapotranspiration rates. To this end, we gathered data on cheatgrass leat area, xylem pressure potential, gas exchange rates with plants on the lysimeters, and gas exchange rates of the soil after the plants had been harvested.

The amount of leaf area present is related to transpiration and evapotranspiration rates. Relyea et al. (1989) concluded that the presence of plants on the small tube lysimeters increased evapotranspiration for all conditions. Leaf area was significantly lower in the sand treatment than in the admix or soil treatments. This may be a result of differences in germination rates, survival to maturity, or size at maturity. Plants in the sand treatment appeared to be more physiologically stressed than those in the other treat nents although the xylem pressure potential of surviving plants in the sand treatrient was rot significantly different from those in the other treatments. The appearance of stress in these plants may also be because of low nitrogen contents in the sand compared with those in the admix and soil treatments. A possible explanation for lower leaf areas might be that the sandy surface could become desiccated more rapidly than the other surfaces causing lower germination rates or higher mortality of young plants. It appears that cheatgrass grows better in the admix and soil surface treatments and may be related to water-holding capacity of the fine soils compared with that of sand and/or soil nitrogen status.

Observed evapotranspiration rates were apparently unaffected by the surface treatments. This may be explained by the manner in which the rates were computed. The rates were based on the surface area of each lysimeter and did not take into account the amount of leaf area in the lysimeters.

When transpiration rates were estimated, significant treatment effects were found. This increase in resolution is because the variation associated with plants is accounted for in the data by relativizing with leaf area. Transpiration rates were lower in the admix and soil treatments compared with rates in the sand treatment. This suggests that the plants in the admix and soil treatments were under more stress than those in the sand treatment. This was the case for the admix and gravel treatments 
where the xylem pressure potential of the plants in the admix treatment was significantly lower than for the plants in the gravel treatment. A similar result was found for the net $\mathrm{CO}_{2}$ uptake flux data except that when rates were converted to net photosynthesis by basing rates on leaf area, there still were no evident effects of treatments.

We investigated soil gas exchange processes after plant material had been removed to determine if the gas exchange system was sensitive enough to measure the relatively low rates of soil evaporation and respiration from apparently dry surfaces. The gas exchange system proved to be sensitive enough to measure soil gas exchange processes. This capability may be used to increase our understanding of soil gas exchange processes. The main treatment effect for soil evaporation was the nearly threefold greater rate for the gravel surface compared with the sand surface. This may be explained as the result of the greater boundary resistance to gas diffusion that sand has relative to gravel. A similar result was found for soil respiration where rates from the sand treatment were significantly lower than those in the soil treatment. This resuit is probably due to a likely lower root biomass in the sand treatment than in the soil treatment. Although we did not measure root biomass, it is likely that the lower leaf area in the sand treatment also suggests that there is less root material. Because we measured soil gas exchange within a few days of harvesting the sioot material and because we observed shoot regrowth, we assume that roots were still active and capable of significant respiration.

Evapotranspiration, measured over a year, was greater in the soil and admix treatments compared with the sand and gravel treatments (Relyea et al. 1989). We found no effect of the treatments on evapotranspiration; however, at the time of these experiments, we observed less transpiration in the admix lysimeter than in the sand or gravel lysimeter. This is a reflection of xylem pressure differences as a result of less available water in the admix lysimeters than in the sand or gravel lysimeter. Our data are instantaneous compared with the integrated values found in Relyea et al. (1989), making comparisons difficult.

In summary, the gas exchange system operated better than expected in that it was sensitive enough to measure low rates of soil gas exchange. Evapotranspiration rates on lysimeters with plants were about five times greater than evaporation rates on lysimeters with the plants removed. Soil evaporation rates were higher on the gravel surfaces than on the sand surfaces. Transpiration rates were higher for plants in the sand treatment than for plants in the admix and soil treatments. 


\subsection{EUTURE WORK}

Future work with the gas exchange system should concentrate on model development so that we can predict how much water various species will remove from the soil. We propose the construction of replicate chambers and a large chamber for full-size shrub gas exchange work at McGee Ranch. The relationship between gas exchange processes and environmental driving variables should be systematically developed. This will require some modifications to the gas exchange system used this year. In addition, more data need to be gathered on whole plant leaf area dynamics and soil water contents. 


\subsection{REFERENCES}

Adams, M. R. and N. R. Wing. 1986. Protective Barrier and Warning Marker System Development Plan. RHO-RE-PL-35, Rockwell Hanford Operations, Richland, Washington.

Blooin, A. J, H. A. Mooney, O. Bjorkmman, and J. Berry. 1980. "Materials and Methods for Carbon Dioxide and Water Exchange Analysis." Plant. Cell. and Environ. 3:371376.

Caldwell, M. C., T. J. Dean, R. S. Nowak, R. S. Dzurec, and J. H. Richards. 1983. "Bunchgrass Architecture, Light Interception, and Water Use Efficiency: Assessment by Fiber Optic Point Quadrats and Gas Exchange." Oecologia 59:178-184.

Duncan, D. B. 1975. "T-tests and Intervals for Comparisons Suggested by the Data." Biometrics 31:339-359.

Gee, G. W., R. R. Kirkham, J. L. Downs, and M. D. Campbell. 1989. The Field Lysimeter Test Facility (FLIF) at the Hanford Site: Installation and Initial Tests. PNL-6810, Pacific Northwest !aboratory, Richland, Washington.

Link, S. O., and W. J. Waugh. 1989. Evapotranspiration Studies for Protective Barriers: Experimental Plans. PNL-6899, Pacific Northwest Laboratory, Richland, Washington.

Link, S. O., M. E. Thiede, R. D. Evans, J. L. Downs, and W. J. Waugh. 1989.

Evapotranspiration Studies for Protective Barriers: FY 1988 Status Report. PNL-6985, Pacific Northwest Laboratory, Richland, Washington.

Relyea, J. F., M. R. Sackschewsky, and W. J. Waugh. 1989. Small-Tube Lysimeter Facility Status Report for Fiscal Year 1989. WHC-EP-0297, Westinghouse Hanford Company, Richland, Washington.

Tranquillini, W., and M. C. Caldwell. 1972. "Integrated Calibrations of Plant Gas Exchange Systems." Ecolegy 53:974-976.

U.S. Department of Energy (USDOE). 1987. Disposal of Hanford Defense HighLevel. Transuranic and Tank Wastes. DOE/EIS-0113, U.S. Department of Energy, Washington, D. C.

Waugh, W. J., and S. O. Link. 1989. Barrier Erosion Control TestPlan: GraveL Mulch. Vegetation and Soil Water Interactions. WHC-EP-0067, Westinghouse Hanford Company, Richland, Washington. 


\section{DISTRIBUTION}

No. of

Copies

\section{OFFSITE}

2 DOE/Office of Scientific and

Technical Information

2 Los Alamos National Laboratory

P. O. Box 1663

Los Alamos, NM 87545

ATTN: T. E. Hakonson

J. W. Nylan

2 U. S. Ecology

P. O. Box 7246

9200 Shelbyville Rd

Suite 526

Louisville, KY 40207

ATTN: R. E. Sauer

D. Lane

W. Brewer

Office of High-Level Nuclear Waste Management

Washington State Department of Ecology

Olympia, WA 98504

2 Agronomy Department

Washington State University

Pullman, WA 99164

ATTN: A. J. Busacca

G. S. Campbell

E. M. Carlin

Low-Level Radioactive Waste Program

Washington Department of Ecology

Mail Stop PV-11

Olympia, WA 98504
No. of

Copies

Chem Nuclear Geotech

P.O. Box 14000

Grand Junction, CO 81502

ATTN: W. J. Waugh

2 U. S. Department of Energy

785 DOE Place

Idaho Falls, ID 83402

ATTN: O. D. Markham

T. E. Reynolds

EG\&G Idaho, Inc.

P. O. Box 1625

Idaho Falls, ID. 83415-3900

ATTN: K. M. Kostelnik

C. Massimino

U. S. Environmental Protection Agency

1200 Sixth Avenue

Seattle, WA 98101

Alan Rainey

Department of Health

Radiation Protection Division

Airdustrial Park

Bldg. 5, M.S. LE-13

Olympia, WA 98504

3 Low-Level Radioactive Waste

Program

U.S. Geological Survey

Water Resources Division

12201 Sunrise Valley Drive

Reston, VA 22092

ATTN: J. Fisher

$P$. Stevens

N. Trask 
No. of

Copies

L. Frank

U.S. Department of Energy

625 Marion Street, N.E.

Salem, OR 97310

D. Hillel

Department of Plant and Soil

Science

12A Stockbridge Hall

University of Massachusetts

Amherst, MA 01003

David E. Daniel

Department of Civil Engineering

University of Texas

Austin, TX 78712

Gregory N. Richardson

Hazen and Sawyer

4011 W. Chase Blvd.

Suite 500

Raleigh, NC 27607

Lorne G. Everett

Metcalf and Eddy Consultants, Inc.

PO Box 24110

Santa Barbara, CA 93121

Charles Reith

Jacobs Engineering

Weldon Springs Site

St. Charles, MO 63301

Geoff W. Spaulding

Dames and Moore

Suite 108

4220 S. Maryland Pkwy.

Las Vegas, NV 89119

E. M. Romney

Laboratory of Biomedical and Environmental Sciences

University of California

Los Angeles, CA 90024
No. of

UC-702
N. Ingraham

Desert Research Institute

Suite 1

2505 Chandler Avenue

Las Vegas, NV 89120

Thomas Nash

Department of Botany

Arizona State University

Tempe, AZ 85287

Martyn Caldwell

Department of Range Science

Utah Siate University

Logan, UT 84322

R. Alan Black

Department of Botany

Washington State University

Pullman, WA 99164

I. Winograd

U.S. Geological Survey

MS 432

Reston, VA 22092

R. Treat

EBASCO

Richland, WA 99352

2 Geology Department

Washington State University

Pullman, WA 99164

ATTN: K. Keller

D. Gaylord

L. J. Fritschen

Forestiy Department

University of Washington

Seattle, WA 98195

2 Washington State Department of Ecology

MS-PU-11

Olympia, WA 98504-8711

ATTN: C. Cline

R.B. Hibbard 
Nc. of

Copies

3 Hanford Project Office

U.S. Environmental Protection Agency

712 Swift

Richland, WA 99352

ATTN: D.A. Faulk, A7-70

P. S. Innis, A7-70

D. R. Sherwood, A7-70

\section{ONSITE}

10 DOE Richland Field Office

G. J. Braken

J. J. Broderick

R.P. Carter

R. D. Freeburg

R. E. Gerton

J. D. Goodenough

A.C. Harris

J. M. Hennig

R. D. Izatt

J. P. Sands

3 Kaiser Engineers Hanford

S.D. Consort

D.L. Fort

D.L. Watkins

36 Westinghouse Hanford

company

M. R. Adams

W.C Alaconis

J. D. Berger

R. J. Bliss

L. C. Brown

J. W. Cammann

R. A. Carlson

J. D. Davis

C. J. Geier

R.L. Gilchrist

W. F. Heine

J. M. Henderson
No. of

Copies

G. W. Jackson

K. N. Jordan

C. J. Kemp

D. S. Landeen

R. E. Lerch

H. E. McGuire

D. R. Myers

D. J. Newland

B. E. Opitz

K. L. Petersen

S. J. Phillips

R. C. Roos

M. R. Sackschewsky

J. L. Scott

J. C. Sonnichsen

D. R. Speer

J. A. Voogd

S. A. Weigman

G. W. Williamson

N. R. Wing

D. D. Wodrich

R. D. Wojtasek

J.C. Womack

D. E. Wood

45 Pacific Northwest Laberatory

L. L. Cadwell

M. D. Campbell

J. C. Chatters

J. L. Downs

L. E. Eberhardt

J. W. Falco

M. J. Fayer

M. G. Foley

H. D. Freeman

G. W. Gee

M. G. Graham

P. C. Hays

C. T. Kincaid

R. R. Kirkham

G. V. Last

M. W. Ligotke

S. O. Link (10)

M. L. Rockhold 
PNL-8033

UC-702

No. of

Copies
L. E. Rogers
M. A. Simmons
R. L. Skaggs
S. C. Slate
D. L. Stewart
T. L. Stewart
J. A. Stottler:iyre

No. of

Copies
G. P. Streile
M. E. Thiede
J. M. Thomas
W. H. Walters
R. E. Wildung
Publishing Coordination
Technical Report Files (5) 


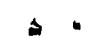
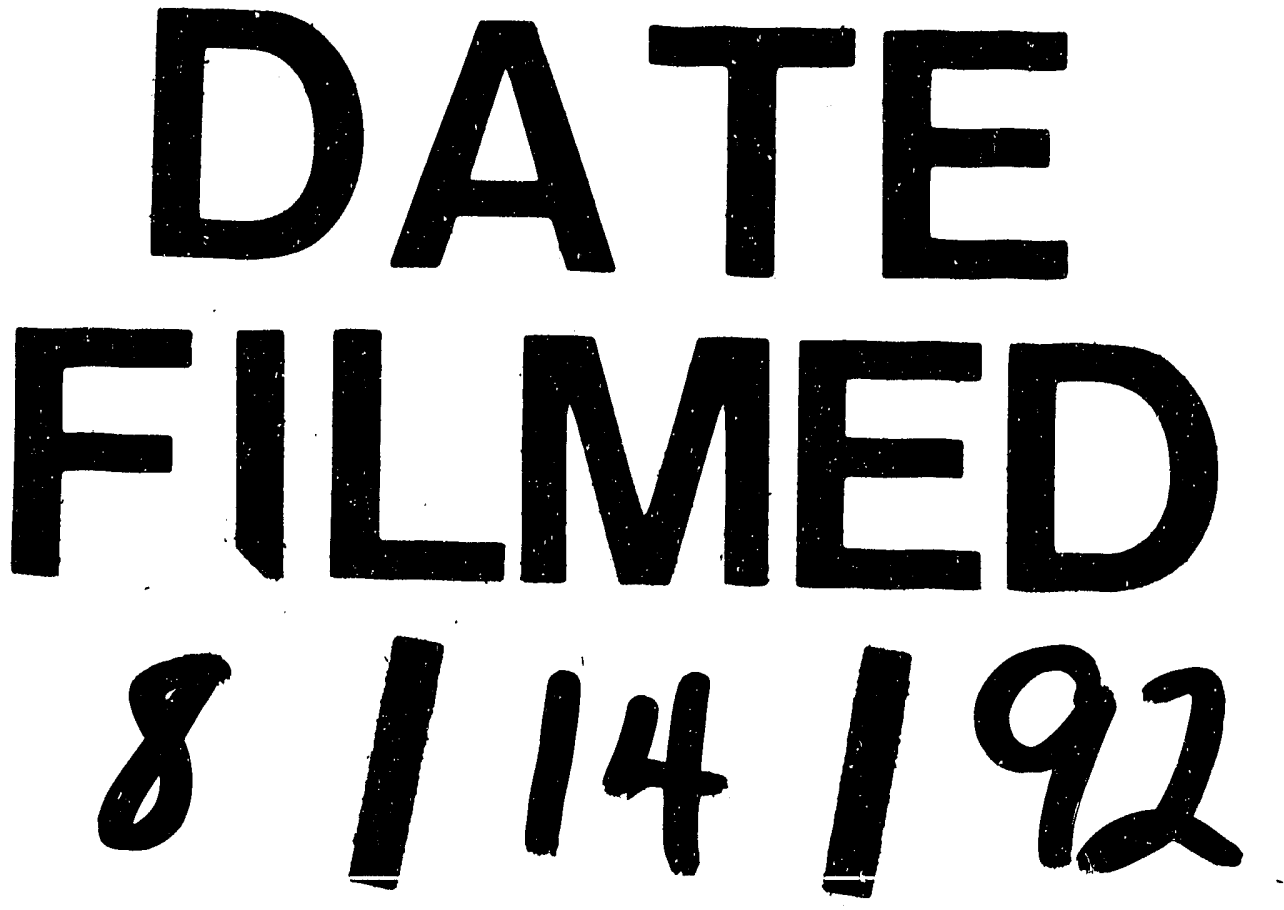